\title{
Thermal stability of hybrid materials based on epoxy functional (poly)siloxanes
}

\author{
Hieronim Maciejewski • Izabela Dąbek • \\ Ryszard Fiedorow $\cdot$ Michał Dutkiewicz • \\ Mariusz Majchrzak
}

Received: 8 September 2011 / Accepted: 8 November 2011/Published online: 23 November 2011

(C) The Author(s) 2011. This article is published with open access at Springerlink.com

\begin{abstract}
Epoxy functional (poly)siloxanes are one of the most important classes of modified silicones. Due to high reactivity of epoxy group and specific features of siloxane chain, they can make an excellent raw material for synthesis of hybrid materials. Results obtained in this study have shown that both the modification of epoxy resins with epoxy functional disiloxanes as well as the application of polysiloxanes with long polysiloxane chains and a specified content of epoxy groups makes it possible to produce hybrid materials of very good thermal stability. Crosslinking reactions were carried out with use of four diamines of which the best one appeared to be 4,4'-diaminodiphenylmethane. The highest thermal stability was found in the case of hybrid materials obtained from epoxy functional polysiloxanes.
\end{abstract}

Keywords Epoxy functional polysiloxanes - Hybrid materials · Crosslinking reactions - Thermal stability · DSC measurements

\section{Introduction}

Fast technological progress and striving to develop materials with newer and newer properties generate a great demand for modern materials. Many well-known materials, such as

H. Maciejewski ( $₫) \cdot$ R. Fiedorow · M. Dutkiewicz ·

M. Majchrzak

Faculty of Chemistry, Adam Mickiewicz University,

Grunwaldzka 6, 60-780 Poznan, Poland

e-mail: maciejm@amu.edu.pl

H. Maciejewski · I. Dąbek

Poznań Science and Technology Park, Rubież 46,

61-612 Poznan, Poland metals, ceramics and plastics, cannot meet requirements set by new directions of applications. In recent years, studies on modern hybrid materials of extraordinary and unprecedented properties became one of the most thriving activities in the field of materials chemistry [1-3]. The term hybrid material denotes a material that contains two components mixed on a molecular level and, most often, one of them is organic and another inorganic in its nature. Among the most popular and universally applied inorganic polymers are polydimethylsiloxanes, colloquially called silicones, which due to their specific properties have found many applications [4-6]. However, a characteristic feature of this class of compounds is also their chemical inertness, therefore, to make reactive silicones; a modification of polysiloxane chains is performed by introducing various functional groups [7, 8]. One of the most popular modified silicones are epoxy functional siloxanes. They have been well-known and used for a lot of various applications since many years [9-16]. Epoxy functional siloxanes offer the benefits of both silicone resins and epoxy resins. The presence of inorganic and organic functionalities in a single polymer results in a unique combination of such properties like weatherability, UV resistance and thermooxidative stability $[17,18]$. The high reactivity of the oxirane ring of epoxides makes it possible to obtain a wide range of compounds or organic-inorganic hybrid polymers. Siloxanes are used for the modification of epoxy resins. Conventionally, the introduction of siloxane into polymers has been carried out through blending methods. The blending of siloxane and epoxy monomers causes an increase in viscosity of the blended resin [19]. It may also cause phase separation and release of siloxane component [20]. Thus, to solve this problem, it is necessary to incorporate a siloxane moiety into the polymer backbone through some chemical reactions. Several different approaches have been applied by using the reaction of epoxy monomers with siloxanes having terminal hydroxy groups 
[21-24], not fully condensed silsesquioxanes, e.g. phenyltrisilanol POSS [25], siloxanes containing amino groups [2630] as well as amino functional silsesquioxanes [31]. Another method of producing hybrid materials was the process of photo-crosslinking of epoxy functional trialkoxysilanes followed by hydrolysis and sol-gel condensation [32, 33]. Most of the materials manufactured in such a way are applied to the preparation of anticorrosive coatings. Recently, it was reported that also epoxy functional siloxanes crosslinked with aminopropyltrialkoxysilanes found an application to anticorrosive coatings $[34,35]$. Therefore, it is worth to prepare and investigate properties of materials based on different epoxy functional (poly)siloxanes.

Our contribution to this field were syntheses, isolation and characterisation of many epoxy functional di-, tri- and polysiloxanes containing glycidoxy and 3,4-epoxycyclohexyl group in various amounts. Such compounds were synthesised via hydrosilylation reaction of appropriate (poly)hydromethylsiloxane with allyl glycidyl ether or 1-vinyl-3,4epoxycyclohexane, in the presence of highly efficient catalytic system based on rhodium siloxide complex immobilised in ionic liquids [36].

Studies presented in this study were aimed at determining thermal stability of hybrid materials based on different epoxy functional siloxanes and (poly)siloxanes crosslinked with various diamines as well as at determining energetic effects observed during curing epoxyfunctional (poly)siloxanes and their blends with commercial epoxy resin in the presence of various diamines used as curing agents.

\section{Experimental}

All syntheses and manipulations were carried out under argon using standard vacuum techniques. ${ }^{1} \mathrm{H},{ }^{13} \mathrm{C}$ and ${ }^{29} \mathrm{Si}$ NMR spectra were recorded on a Varian Gemini 300 VT and Varian Mercury 300 VT spectrometers. Mass spectra of the monomers were obtained by GC-MS analysis (Varian Saturn 2100T equipped with a 30-m capillary column BD-5 and an ion trap detector). High-resolution mass spectroscopic analyses were performed on an AMD-402 mass spectrometer and FAB mass spectra on an AMD-604 instrument (AMD Intectra GmbH). FT-IR spectra were recorded on a Bruker Tensor 27 Fourier transform spectrometer equipped with a SPECAC Golden Gate diamond ATR unit. DSC measurements were carried out under nitrogen (flow rate of $50 \mathrm{~mL} / \mathrm{min}$ ) at a heating rate of $10{ }^{\circ} \mathrm{C} /$ min using a differential scanning calorimeter DSC-1 (MettlerToledo). The preparation of samples for DSC experiments consisted in weighing appropriate amounts of reactants (epoxy compound and diamine) into a beaker directly before measurements, while maintaining the stoichiometry of two epoxy groups per one amino group and vigorously stirred. About $10 \mathrm{mg}$ of a mixture (in the form of liquid or suspension) prepared in such a way was placed in a $40-\mu \mathrm{L}$ aluminium pan with a pierced lid and the measurement was performed immediately after that. Thermogravimetry was performed on a Q50 (TA Instruments) analyser. A sample of a hybrid material was placed on a thermobalance platinum pan at room temperature in nitrogen flow of $40 \mathrm{~mL} / \mathrm{min}$. After $3 \mathrm{~min}$, heating of the sample to $600{ }^{\circ} \mathrm{C}$ began at the rate of $10{ }^{\circ} \mathrm{C} / \mathrm{min}$.

\section{Materials}

The chemicals were obtained from the following suppliers: toluene $(>99.95 \%)$, ethylenediamine ( $>99.5 \%)$, 1,3-diaminopropane (>99\%), 1,6-diaminohexane (98\%) and 4,4'diaminodiphenylmethane $(>97 \%)$ were purchased from Sigma-Aldrich, diglycidyl ether of bisphenol A ( $>92 \%)$ from Fluka and $\mathrm{CDCl}_{3}$ from Dr. Glaser A.G. Basel. Each diamine was degassed under vacuum at a low temperature and left under argon atmosphere. All the syntheses of monomers and catalytic tests were carried out under argon atmosphere. 3-(3glycidoxypropyl)-1,1,1,3,5,5,5-heptamethyltrisiloxsane, 1,3bis(3-glycidoxypropyl)-1,1,3,3-tetramethyldisiloxane and poly (dimethyl-co-(glycidoxypropyl)methyl)siloxanes were prepared according to procedures reported in the literature via hydrosilylation reactions catalysed by Rh-complex [36, 37].

\section{General procedure for synthesis of model compounds of type 1}

An oven dried 15-mL two-neck glass reactor equipped with reflux condenser and connected to gas and vacuum lines was charged under argon with $2.97 \times 10^{-3} \mathrm{~mol}(1.013 \mathrm{~g})$ of [3(glycidoxypropyl]-1,1,1,3,5,5,5-heptamethyltrisiloxane) and $1.485 \times 10^{-3} \mathrm{~mol}$ of diamine (amount depending on substrate purity).

The reaction mixture was heated at $110{ }^{\circ} \mathrm{C}$ for $3-8 \mathrm{~h}$. Conversions of the substrates were monitored by GC-MS and FT-IR analyses. After the reaction was completed, the crude mixture was allowed to stand under vacuum for 20 min. Reaction yields and the purity of final product were calculated on the basis of the ${ }^{1} \mathrm{H}$ NMR and IR spectra.

Analytical data

\section{$1 a$}

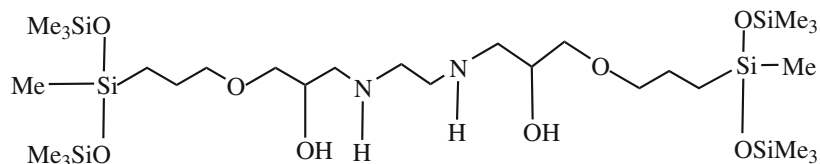

Viscous colourless liquid, yield $89 \%$, purity $98 \%$. 
${ }^{1} \mathrm{H}$ NMR(300 MHz, $\left.\mathrm{C}_{6} \mathrm{D}_{6}\right): \delta 0.14\left[\mathrm{~s}, 6 \mathrm{H},-\mathrm{Si}\left(\mathrm{CH}_{3}\right)-\right], 0.21$ $\left[\mathrm{s}, 36 \mathrm{H},-\mathrm{Si}\left(\mathrm{CH}_{3}\right)_{3}\right], 0.97\left(\mathrm{t}, 4 \mathrm{H}, \mathrm{SiCH}_{2}-\right), 1.72(\mathrm{~m}, 4 \mathrm{H}$, $\mathrm{SiCH}_{2} \mathrm{CH}_{2}-$ ), 2.67 (s, 4H, $-\mathrm{HN}-\mathrm{CH}_{2} \mathrm{CH}_{2}-\mathrm{NH}-$ ), 2.96 (s, 2H, $-\mathrm{NH}-), 3.03$ (m, 2H, - $\mathrm{CH}-), 3.33$ and $3.37(\mathrm{~m}, 8 \mathrm{H}$, $\left.-\mathrm{CH}_{2} \mathrm{OCH}_{2}-\right), 3.47\left(t, 4 \mathrm{H},-\mathrm{CH}_{2} \mathrm{OH}\right), 4.09$ (s, 2H, $\left.\mathrm{CH}_{2} \mathrm{OH}\right)$.

${ }^{13} \mathrm{C}$ NMR $\left(79 \mathrm{MHz}, \mathrm{C}_{6} \mathrm{D}_{6}\right): \delta-0.1 \quad\left(\mathrm{SiCH}_{3}\right), 2.0$ $\left[\mathrm{Si}\left(\mathrm{CH}_{3}\right)_{3}\right], 14.1\left(\mathrm{SiCH}_{2}-\right), 23.9\left(-\mathrm{CH}_{2}-\right), 49.4(-\mathrm{HN}-$ $\left.\mathrm{CH}_{2} \mathrm{CH}_{2} \mathrm{NH}-\right)$, $59.1\left(\mathrm{O}-\mathrm{CH}_{2}-\mathrm{CH}<\right), 60.9\left(-\mathrm{CH}_{2} \mathrm{OH}\right), 69.4$ $\left(\mathrm{O}-\mathrm{CH}_{2}-\mathrm{CH}<\right), 74.3\left(-\mathrm{CH}_{2}-\mathrm{CH}_{2}-\mathrm{O}-\right)$.

${ }^{29} \mathrm{Si} \mathrm{NMR}\left(60 \mathrm{MHz}, \mathrm{C}_{6} \mathrm{D}_{6}\right): \delta-21.12\left[-\mathrm{Si}\left(\mathrm{CH}_{3}\right)_{3}\right], 7.14$ $\left(\mathrm{SiCH}_{3}\right)$.

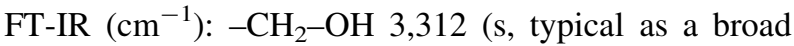
band).

MS [FAB, $m / z(\%)] 733\left(\mathrm{M}^{+}, 100\right)$.

\section{$1 b$}

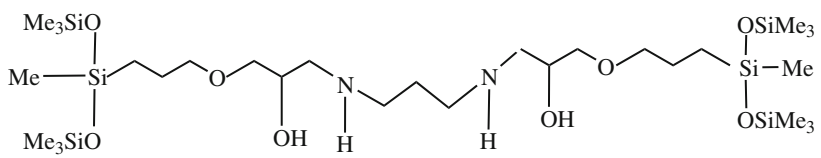

Viscous colourless liquid, yield $89 \%$, purity $96 \%$.

${ }^{1} \mathrm{H} \mathrm{NMR}\left(300 \mathrm{MHz}, \mathrm{C}_{6} \mathrm{D}_{6}\right): \delta 0.14\left[\mathrm{~s}, 6 \mathrm{H},-\mathrm{Si}\left(\mathrm{CH}_{3}\right)-\right]$, $0.21\left[\mathrm{~s}, 36 \mathrm{H},-\mathrm{Si}\left(\mathrm{CH}_{3}\right)_{3}\right], 0.98\left(t, 4 \mathrm{H}, \mathrm{SiCH}_{2}-\right), 1.71$ (m, $4 \mathrm{H}, \mathrm{SiCH}_{2} \mathrm{CH}_{2}-$ ), 2.55 (q, $\left.2 \mathrm{H},-\mathrm{CH}_{2}-\mathrm{CH}_{2}-\mathrm{CH}_{2}-\right), 2.66$ (s, 4H, - HN-CH $\mathrm{CH}_{2}-\mathrm{NH}-$ ), 2.84 (s, 2H, -NH-), 3.03 $(\mathrm{m}, 2 \mathrm{H},-\mathrm{CH}-), 3.33$ and $3.38\left(\mathrm{~m}, 8 \mathrm{H},-\mathrm{CH}_{2} \mathrm{OCH}_{2}-\right), 3.47$ $\left(t, 4 \mathrm{H},-\mathrm{CH}_{2} \mathrm{OH}\right), 3.92$ (s, 2H, $\left.\mathrm{CH}_{2} \mathrm{OH}\right)$.

${ }^{13} \mathrm{C}$ NMR $\left(79 \mathrm{MHz}, \mathrm{C}_{6} \mathrm{D}_{6}\right): \quad \delta \quad-0.1 \quad\left(\mathrm{SiCH}_{3}\right), \quad 2.0$ $\left[\mathrm{Si}\left(\mathrm{CH}_{3}\right)_{3}\right], 14.1\left(\mathrm{SiCH}_{2}-\right), 23.9\left(-\mathrm{CH}_{2}-\right), 26.2\left(-\mathrm{CH}_{2}-\mathrm{CH}_{2}-\right.$ $\left.\mathrm{CH}_{2}-\right), 49.4\left(-\mathrm{HN}-\mathrm{CH}_{2} \mathrm{CH}_{2} \mathrm{NH}-\right), 59.1\left(\mathrm{O}-\mathrm{CH}_{2}-\mathrm{CH}<\right), 60.9$ $\left(-\mathrm{CH}_{2} \mathrm{OH}\right), 69.4\left(\mathrm{O}-\mathrm{CH}_{2}-\mathrm{CH}<\right), 74.3\left(-\mathrm{CH}_{2}-\mathrm{CH}_{2}-\mathrm{O}-\right)$.

${ }^{29} \mathrm{Si} \mathrm{NMR}\left(60 \mathrm{MHz}, \mathrm{C}_{6} \mathrm{D}_{6}\right): \delta-21.18\left[-\mathrm{Si}\left(\mathrm{CH}_{3}\right)_{3}\right], 7.09$ $\left(\mathrm{SiCH}_{3}\right)$.

FT-IR $\left(\mathrm{cm}^{-1}\right)$ : $-\mathrm{CH}_{2}-\mathrm{OH} 3,394$ (s, typical as a broad band). MS [FAB, $m / z(\%)] 747\left(\mathrm{M}^{+}, 100\right)$.

\section{$1 c$}

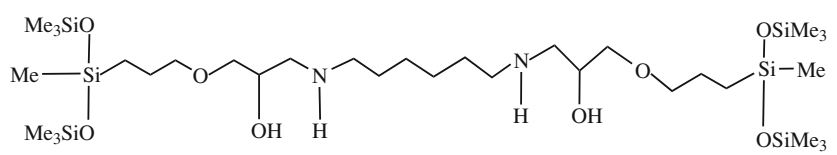

Viscous yellow liquid, yield $83 \%$, purity $95 \%$.

${ }^{1} \mathrm{H} \mathrm{NMR}\left(300 \mathrm{MHz}, \mathrm{C}_{6} \mathrm{D}_{6}\right): \delta 0.15\left[\mathrm{~s}, 6 \mathrm{H},-\mathrm{Si}\left(\mathrm{CH}_{3}\right)-\right]$, $0.22\left[\mathrm{~s}, 36 \mathrm{H},-\mathrm{Si}\left(\mathrm{CH}_{3}\right)_{3}\right], 0.99\left(t, 4 \mathrm{H}, \mathrm{SiCH}_{2}-\right), 1.28(t, 4 \mathrm{H}$, $-\mathrm{CH}_{2}-$ ), 1.43 (q, 4H, $-\mathrm{CH}_{2}-$ ), 1.71 (m, 4H, $\mathrm{SiCH}_{2} \mathrm{CH}_{2}-$ ), $2.55\left(t, 4 \mathrm{H},-\mathrm{CH}_{2}-\right), 2.84(\mathrm{~s}, 2 \mathrm{H},-\mathrm{NH}-), 3.02(\mathrm{~m}, 2 \mathrm{H}$, $-\mathrm{CH}-), 3.31$ and $3.37\left(\mathrm{~m}, 8 \mathrm{H},-\mathrm{CH}_{2} \mathrm{OCH}_{2}-\right), 3.46(t, 4 \mathrm{H}$, $\left.-\mathrm{CH}_{2} \mathrm{OH}\right), 3.91$ (s, 2H, $\left.\mathrm{CH}_{2} \mathrm{OH}\right)$.

${ }^{13} \mathrm{C}$ NMR $\left(79 \mathrm{MHz}, \mathrm{C}_{6} \mathrm{D}_{6}\right): \delta-0.09\left(\mathrm{SiCH}_{3}\right), 1.9$ $\left[\mathrm{Si}\left(\mathrm{CH}_{3}\right)_{3}\right], 18.1\left(\mathrm{SiCH}_{2}-\right), 26.5\left(-\left(\mathrm{CH}_{2}\right)_{2}-\mathrm{CH}_{2}-\left(\mathrm{CH}_{2}\right)_{2}-\right)$,
$27.2\left(\mathrm{Si}-\mathrm{CH}_{2}-\mathrm{CH}_{2}-\right), 29.7\left[-\left(\mathrm{CH}_{2}\right)_{2}-\mathrm{CH}_{2}-\left(\mathrm{CH}_{2}\right)_{2}-\right], 49.4$ $\left(-\mathrm{HN}-\mathrm{CH}_{2}\left(\mathrm{CH}_{2}\right)_{4} \mathrm{CH}_{2} \mathrm{NH}-\right), \quad 59.1 \quad\left(\mathrm{O}-\mathrm{CH}_{2}-\mathrm{CH}<\right), \quad 61.3$ $\left(-\mathrm{CH}_{2} \mathrm{OH}\right), 68.3\left(\mathrm{O}-\mathrm{CH}_{2}-\mathrm{CH}<\right), 72.9\left(-\mathrm{CH}_{2}-\mathrm{CH}_{2}-\mathrm{O}-\right)$.

${ }^{29} \mathrm{Si} \mathrm{NMR}\left(60 \mathrm{MHz}, \mathrm{C}_{6} \mathrm{D}_{6}\right): \delta-21.19\left[-\mathrm{Si}\left(\mathrm{CH}_{3}\right)_{3}\right], 7.16$ $\left(\mathrm{SiCH}_{3}\right)$.

FT-IR $\left(\mathrm{cm}^{-1}\right)$ : $-\mathrm{CH}_{2}-\mathrm{OH} 3,396$ (s, typical as a broad band). MS [FAB, $m / z(\%)] 789\left(\mathrm{M}^{+}, 100\right)$.

\section{1d}

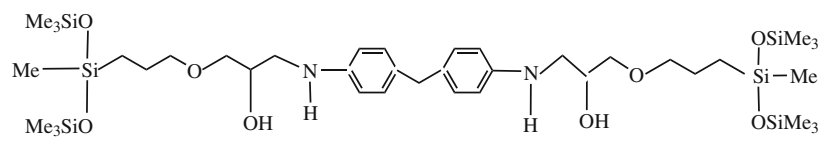

Viscous garish yellow liquid, yield $78 \%$, purity $98 \%$.

${ }^{1} \mathrm{H}$ NMR(300 MHz, $\left.\mathrm{C}_{6} \mathrm{D}_{6}\right): \delta 0.17\left[\mathrm{~s}, 6 \mathrm{H},-\mathrm{Si}\left(\mathrm{CH}_{3}\right)-\right]$, $0.25\left[\mathrm{~s}, 36 \mathrm{H},-\mathrm{Si}\left(\mathrm{CH}_{3}\right)_{3}\right], 0.79\left(t, 4 \mathrm{H}, \mathrm{SiCH}_{2}-\right), 1.80(\mathrm{~m}$, $4 \mathrm{H}, \mathrm{SiCH}_{2} \mathrm{CH}_{2}-$ ), 2.96 (s, 2H, -NH-), 3.03 (m, 2H, -CH-), 3.37 and $3.42\left(\mathrm{~m}, 8 \mathrm{H},-\mathrm{CH}_{2} \mathrm{OCH}_{2}-\right), 3.47(t, 4 \mathrm{H}$, $\left.-\mathrm{CH}_{2} \mathrm{OH}\right), 3.76\left(\mathrm{~s}, 2 \mathrm{H},>\mathrm{C}-\mathrm{CH}_{2}-\mathrm{C}<\right), 4.09$ (s, 2H, $\left.\mathrm{CH}_{2} \mathrm{OH}\right), 6.67\left(\mathrm{~d}, 4 \mathrm{H}, J_{\mathrm{HH}}=6.1 \mathrm{~Hz}, 2,2^{\prime}-\mathrm{C}_{6} \mathrm{H}_{4}-\right), 6.87(\mathrm{~d}$, $\left.4 \mathrm{H}, J_{\mathrm{HH}}=6.2 \mathrm{~Hz}, 3,3^{\prime}-\mathrm{C}_{6} \mathrm{H}_{4}-\right)$.

${ }^{13} \mathrm{C}$ NMR $\left(79 \mathrm{MHz}, \mathrm{C}_{6} \mathrm{D}_{6}\right): \delta-0.01 \quad\left(\mathrm{SiCH}_{3}\right), 2.1$ $\left[\mathrm{Si}\left(\mathrm{CH}_{3}\right)_{3}\right], 14.1 \quad\left(\mathrm{SiCH}_{2}-\right), 23.8\left(\mathrm{Si}-\mathrm{CH}_{2}-\mathrm{CH}_{2}-\right), 40.7$ $\left(>\mathrm{C}_{\mathrm{i}}-\mathrm{CH}_{2}-\mathrm{C}_{\mathrm{i}}<\right), 55.6\left(\mathrm{O}-\mathrm{CH}_{2}-\mathrm{CH}<\right), 58.3\left(-\mathrm{CH}_{2} \mathrm{OH}\right)$, $69.4\left(\mathrm{O}-\mathrm{CH}_{2}-\mathrm{CH}<\right), 74.3\left(-\mathrm{CH}_{2}-\mathrm{CH}_{2}-\mathrm{O}-\right), 114.2(\mathrm{HN}-$ $\left.2,2^{\prime}-\mathrm{C}_{6} \mathrm{H}_{4}-\right), 129.8\left(\mathrm{HN}-3,3^{\prime}-\mathrm{C}_{6} \mathrm{H}_{4}-\right), 145.0\left(>\mathrm{C}_{\mathrm{i}}-\mathrm{CH}_{2}-\right.$ $\left.\mathrm{C}_{\mathrm{i}}<\right), 147.2\left(\mathrm{HN}-\mathrm{C}_{\mathrm{i}}<\right)$.

${ }^{29} \mathrm{Si} \mathrm{NMR}\left(60 \mathrm{MHz}, \mathrm{C}_{6} \mathrm{D}_{6}\right): \delta-21.20\left[-\mathrm{Si}\left(\mathrm{CH}_{3}\right)_{3}\right], 7.33$ $\left(\mathrm{SiCH}_{3}\right)$.

FT-IR $\left(\mathrm{cm}^{-1}\right)$ : $\mathrm{CH}_{2}-\mathrm{OH} 3,372$ (s, typical as a broad band).

MS [FAB, $m / z(\%)] 871\left(\mathrm{M}^{+}, 100\right)$.

\section{Results and discussion}

The reaction between epoxides and primary or secondary amines is a general and very useful method for crosslinking of epoxy resins and this is why we have employed it for the production of hybrid materials by making use of epoxy functional siloxanes. At the first stage, we have carried out studies of a model crosslinking reaction between monoepoxy trisiloxane and an appropriate diamine, as shown in Scheme 1.

Due to relatively low molecular weight of products formed, their isolation and spectroscopic analysis were possible thus enabling to confirm their structure and to determine yields of particular reactions. In order to establish the effect of the kind of amine on the process course, we have applied four amines differing in the length and kind of a linker between amino groups, namely 1,2-diaminoethane, 1,3-diaminopropane, 1,6-diaminohexane and 


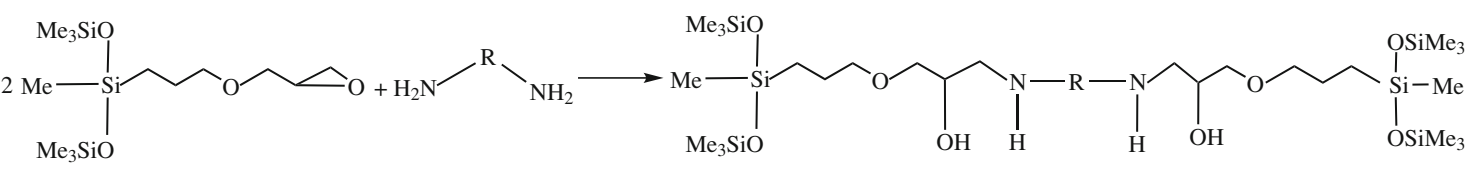

$\begin{array}{ll}\text { 1a } & \mathrm{R}=-\left(\mathrm{CH}_{2}\right)_{2}- \\ \text { 1b } & \mathrm{R}=-\left(\mathrm{CH}_{2}\right)_{3}- \\ \text { 1c } & \mathrm{R}=-\left(\mathrm{CH}_{2}\right)_{6}- \\ \text { 1d } & \mathrm{R}=\end{array}$

Scheme 1 Crosslinking of monoepoxy trisiloxane with various diamines

4,4'-diaminodiphenylmethane. 3-glycidoxypropyl-1,1,1,3, 5,5,5-heptamethyltrisiloxane was mixed with an appropriate diamine at the ratio of 2:1. At the initial stage a slow increase in temperature was observed, then the system was heated up to about $110{ }^{\circ} \mathrm{C}$ and maintained at this temperature until the process was completed, which was determined by means of FT-IR analysis (on the basis of a decrease in the band at $2,100 \mathrm{~cm}^{-1}$ originated from $\mathrm{SiH}$ ) or by means of GC analysis. The process was discontinued when siloxane conversion exceeded $90 \%$ followed by product isolation (by distilling off the excess of reactants) and NMR, FT-IR and MS analyses. Conversions of parent substances and yields of reaction products were listed in Table 1.

It results from Table 1 that yields of products as well as conversions of parent substances are similar. The higher the diamine the slower the reaction, however, the differences are not large. It is known that in diamines each proton (at nitrogen) is active for crosslinking of epoxides, nevertheless, we have used a two-time excess of siloxane (in moles) in order to obtain the product in accordance with Scheme 1 . The formation of such a product was confirmed by the presence of signals originated from $\mathrm{OH}$ groups (in the range of 3.91-4.09 ppm), which appeared as a result of oxirane ring opening, and signals from $\mathrm{NH}$ groups (in the range 2.84-2.96) in ${ }^{1} \mathrm{H}$ NMR spectra. Moreover, mass spectra of particular products recorded by using FAB technique confirmed that molecular weights of the products agree with theoretically predicted ones. Studies of the model reaction enabled also to determine conditions under which the process should be conducted in the further part of research on the reaction of crosslinking between diepoxy functional disiloxane and diamines shown in Scheme 2.

In Scheme 2, for the sake of simplification, the product of reaction of one epoxy group with one proton from amine group was shown, although in fact the stoichiometric ratio of reactants ensured the reaction of each proton of amine group with one epoxy group. After reactions were completed, light yellow, smooth, transparent solids were obtained in each case. To determine energetic effects of
Table 1 Conversions of parent substances and yields of products of reactions between monoepoxy trisiloxane and diamines

\begin{tabular}{lllll}
\hline Product & Time/h & $\begin{array}{l}\text { Conversion of } \\
\text { diamine }(\%)\end{array}$ & $\begin{array}{l}\text { Conversion of } \\
\text { siloxane }(\%)^{\mathrm{a}}\end{array}$ & $\begin{array}{l}\text { Yield } \\
(\%)^{\mathrm{b}}\end{array}$ \\
\hline 1a & 3 & 56 & 59 & 94 \\
& 5 & 94 & 94 & \\
1b & 3 & 53 & 52 & 94 \\
& 6 & 92 & 93 & \\
1c & 3 & 49 & 48 & 90 \\
& 6 & 90 & 92 & 88 \\
1d & 3 & 43 & 40 & \\
& 8 & 90 & 90 & \\
\hline
\end{tabular}

\footnotetext{
${ }^{a}$ Conversion of siloxane was calculated on the basis of GC and FT-IR analyses

b Isolated yield
}

processes investigated, DSC analysis was carried out for reaction systems studied. DSC curves recorded during three reactions that yield products $\mathbf{2 a}, \mathbf{2} \mathbf{b}$ and $\mathbf{2 d}$ are shown by way of illustration in Fig. 1.

All processes studied were exothermic and the higher the diamine the higher reaction enthalpy. The enthalpies determined on the basis of DSC measurements shown in Fig. 1 were $320.1 \mathrm{~J} / \mathrm{g}(\mathbf{2 a}), 398.1 \mathrm{~J} / \mathrm{g}(\mathbf{2 b})$ and $535.3 \mathrm{~J} / \mathrm{g}$ (2d) in the case of 1,2-diaminoethane, 1,3-diaminopropane and 4,4'-diaminodiphenylmethane, respectively. The DSC peak temperatures which were 150 and $148{ }^{\circ} \mathrm{C}$ for reactions with 1,2-diaminoethane and 1,3-diaminopropane, respectively, increased to $206{ }^{\circ} \mathrm{C}$ in the case of diamine of a higher molecular weight such as 4,4'-diaminodiphenylmethane. This indicates that crosslinking in the presence of the latter diamine is the most favourable from the energetic point of view.

The production of a hybrid material with the use of epoxy functional siloxanes can be carried out either by conducting reactions with diamines (as presented above) or by modifying epoxy resins. To compare properties of materials studied (their thermal stability in particular), 
Scheme 2 Crosslinking of diepoxy functional disiloxane with various diamines<smiles>[R]NNCC(O)COCCC[Si](C)(C)O[Si](C)(CCCOCC1CO1)O[Si](C)(C)CCCOCC1CO1</smiles>

$$
\begin{array}{ll}
\text { 2a } & \mathrm{R}=-\left(\mathrm{CH}_{2}\right)_{2}- \\
\text { 2b } & \mathrm{R}=-\left(\mathrm{CH}_{2}\right)_{3}- \\
\text { 2c } & \mathrm{R}=-\left(\mathrm{CH}_{2}\right)_{6}- \\
\text { 2d } & \mathrm{R}=
\end{array}
$$

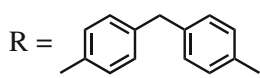

Fig. 1 DSC curves recorded during crosslinking of 1,3 bis(glycidoxypropyl)-1,1,3,3disiloxane in the presence 1,2 diaminoethane (2a), 1,3diaminopropane (2b) and 4,4diaminodiphenylmethane (2d)

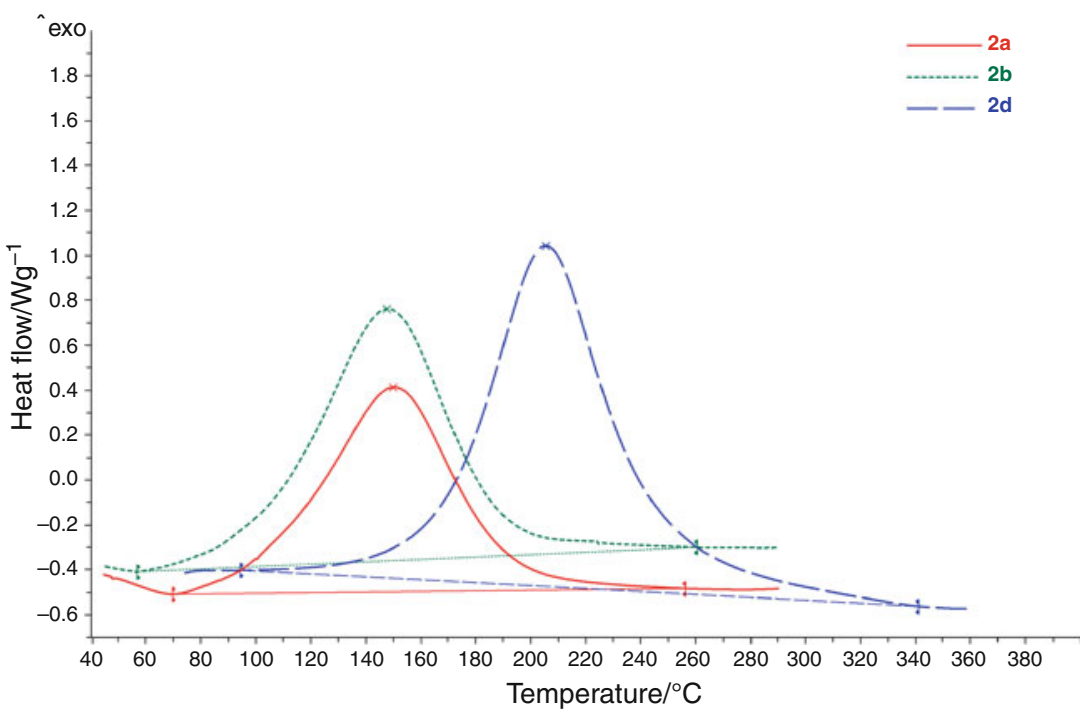

reactions of the classic monomer of epoxy resins, i.e. diglycidyl ether bisphenol A with the same diamines were carried out, as given in Scheme 3.

All products formed as a result of the above reactions were yellow solids, however, only the product $\mathbf{3 d}$ was smooth and transparent, whereas the remaining ones were filled with bubbles in their whole bulk. The enthalpy of the reaction with 4,4'-diaminodiphenylmethane (3d), $494.8 \mathrm{~J} / \mathrm{g}$ as determined by DSC (Fig. 2), is lower than that observed for analogous reaction with diepoxy disiloxane (2d).

At the next stage of the study, mixtures of diepoxy functional disiloxane and diglycidyl ether bisphenol A were prepared at siloxane:epoxide mole ratio equal to 1 and 2 , followed by crosslinking of the mixtures with diamines according to Scheme 4.

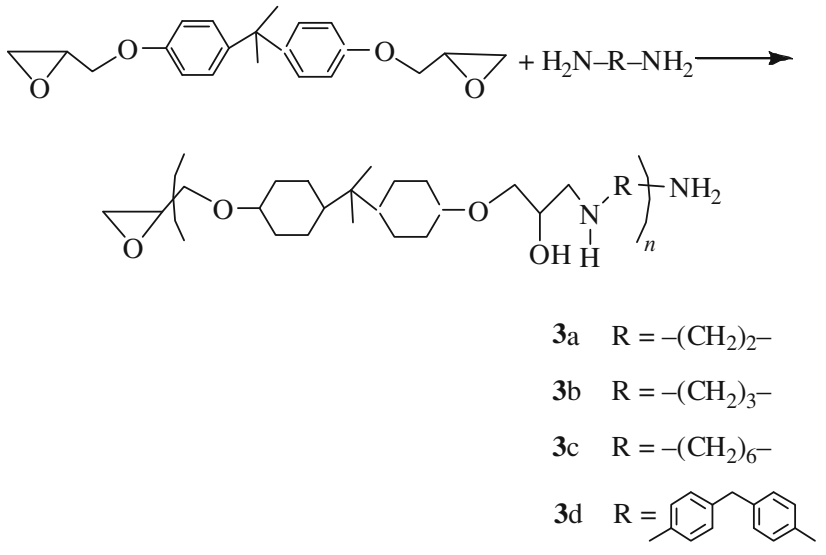

Scheme 3 Reactions of diglycidyl ether of bisphenol A with diamines 
Fig. 2 DSC curves recorded during crosslinking reactions of diepoxy disiloxane (2d), diglycidyl ether of bisphenol A (3d) and their mixture (4d) carried out in the presence of 4,4'-diaminodiphenylmethane
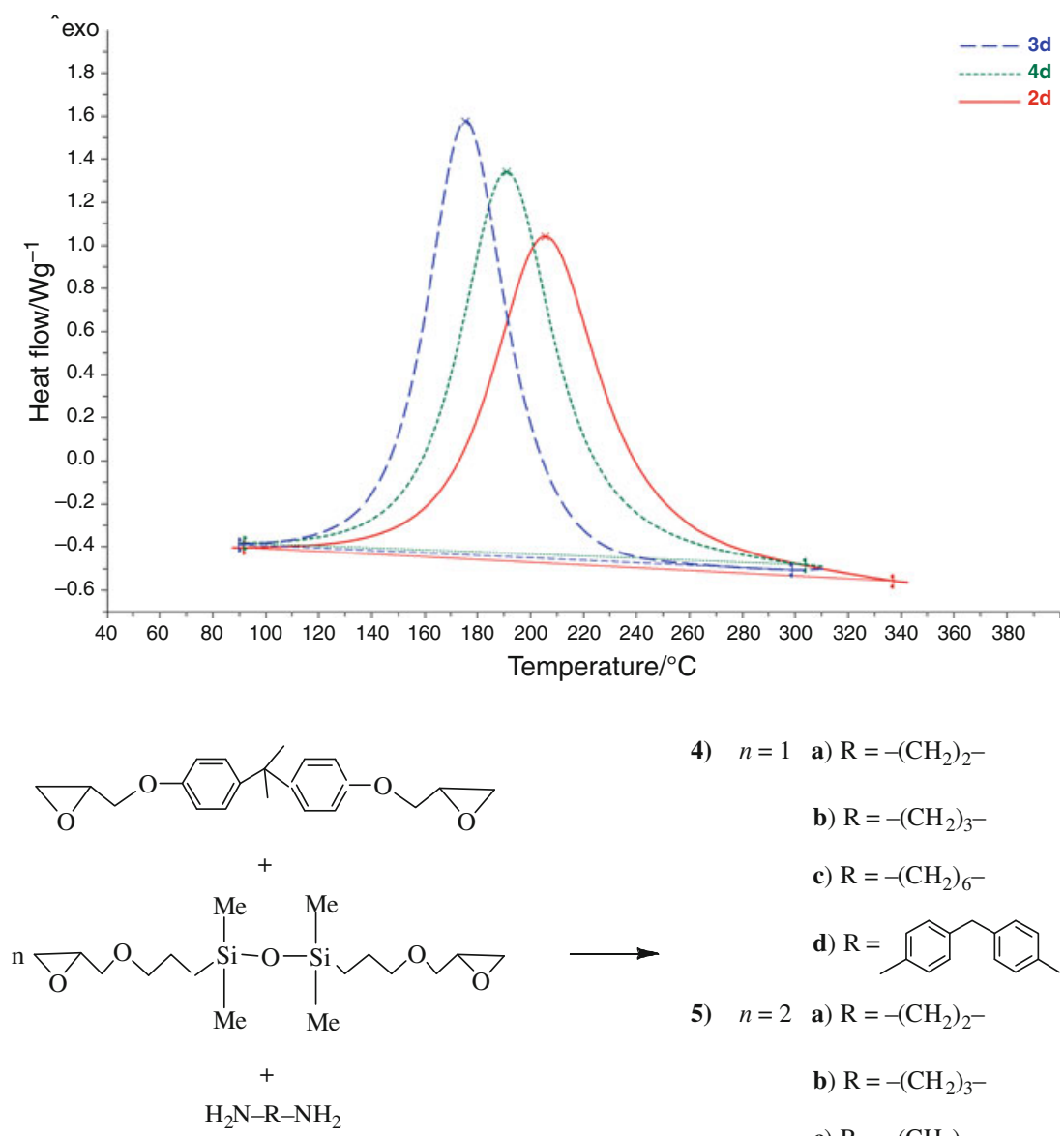

4) $n=1 \quad$ a) $\mathrm{R}=-\left(\mathrm{CH}_{2}\right)_{2}-$

b) $\mathrm{R}=-\left(\mathrm{CH}_{2}\right)_{3}-$

c) $\mathrm{R}=-\left(\mathrm{CH}_{2}\right)_{6}-$

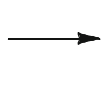

d) $\mathrm{R}=$

5) $n=2$ a) $\mathrm{R}=-\left(\mathrm{CH}_{2}\right)_{2}-$

b) $\mathrm{R}=-\left(\mathrm{CH}_{2}\right)_{3}-$

c) $\mathrm{R}=-\left(\mathrm{CH}_{2}\right)_{6}-$

d) $\mathrm{R}=$
Again qualitatively the best products (smooth and transparent solids) appeared to be $\mathbf{4 d}$ and $\mathbf{5 d}$. DSC measurements performed during the reactions of the siloxaneepoxide mixtures have shown that the energetic effect was in between that determined in the case of pure diepoxy disiloxane and pure epoxy monomer (see Fig. 2). For instance, in the case of 1:1 mixture (4d) the enthalpy of crosslinking reaction is $528.0 \mathrm{~J} / \mathrm{g}$ Table 2 .

Taking into consideration the above results, one can draw a conclusion that it is worth while to prepare hybrid materials with the use of macromolecular epoxy functional (poly)siloxanes crosslinked with diamines. To perform this task we have applied two (poly)siloxanes of different length of siloxane chain and different content of epoxy groups which were subjected to crosslinking with diamines (see Scheme 5).

Similarly as it was in previous cases, also in this case qualitatively the best materials (transparent and without bubbles) were obtained only by reactions with $4,4^{\prime}$-diaminodiphenylmethane. DSC analysis has shown that enthalpies of reactions yielding in products $\mathbf{6 d}$ and $\mathbf{7 d}$ are close one to another and equal to 285.9 and $260.3 \mathrm{~J} / \mathrm{g}$, respectively (Fig. 3). They are considerably lower than that of the
Table 2 Enthalpies $(\Delta H)$ determined for reactions of diepoxy disiloxane (2d), diglycidyl ether of bisphenol A (3d) and their mixture (4d) with 4,4'-diaminodiphenylmethane used as a crosslinking agent

\begin{tabular}{lll}
\hline Sample & Peak temperature $/{ }^{\circ} \mathrm{C}$ & $\Delta H / \mathrm{J} / \mathrm{g}$ \\
\hline 3d & 175 & 494.8 \\
4d & 191 & 528.0 \\
2d & 206 & 534.8 \\
\hline
\end{tabular}

reaction with diepoxy disiloxane, however, values of epoxy numbers of the starting epoxy functional (poly)siloxanes ( 0.304 and 0.284 equiv/100 g, respectively) are significantly lower (almost twice as low as the epoxy number of diepoxy disiloxane which is equal to 0.534 equiv/100 g) and this is why the energetic effect of the mentioned reactions is proportionally smaller. On the other hand, peak temperatures of reactions of the three systems are close to one another and equal to $205^{\circ} \mathrm{C}$.

Of particular interest was a comparison of thermal stabilities of all crosslinked materials. To determine them, thermogravimetric analyses were performed for all samples 
Scheme 5 (Poly)siloxanes of different siloxane chain lengths (m) and different contents of epoxy groups $(n)$ subjected to crosslinking with diamines

$$
\begin{array}{ll}
\text { 6) } m=50 \quad n=25 & \text { a) } \mathrm{R}=-\left(\mathrm{CH}_{2}\right)_{2}-
\end{array}
$$

b) $\mathrm{R}=-\left(\mathrm{CH}_{2}\right)_{3}-$

c) $\mathrm{R}=-\left(\mathrm{CH}_{2}\right)_{6}-$

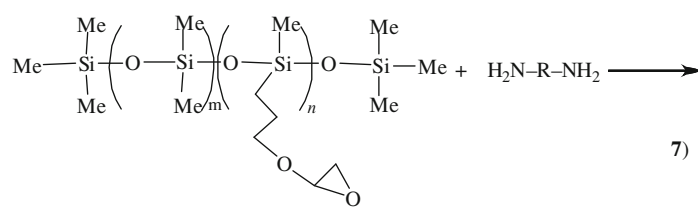

d) $\mathrm{R}=$

$\begin{array}{lll}m=70 \quad n=30 & \text { a) } \mathrm{R}=-\left(\mathrm{CH}_{2}\right)_{2}-\end{array}$

b) $\mathrm{R}=-\left(\mathrm{CH}_{2}\right)_{3}-$

c) $\mathrm{R}=-\left(\mathrm{CH}_{2}\right)_{6}-$

d) $\mathrm{R}=$
Fig. 3 DSC curves recorded during crosslinking reactions of (poly)siloxanes of different siloxane chain lengths and different contents of epoxy groups with 4,4'diaminodiphenylmethane

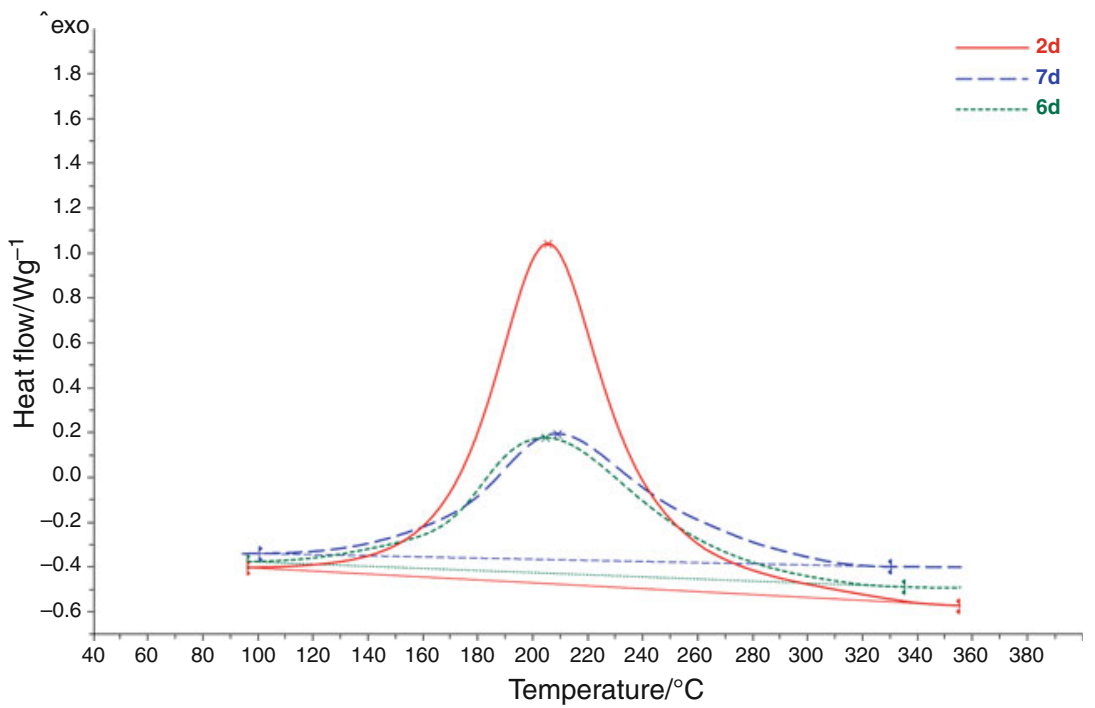

(labelled from 2 to 7). Already for the first samples examined (2a-2d) a clear parallelism was found between TGA and DSC results. The enthalpy of the reaction yielding the sample 2d was the highest and so was thermal stability of the above sample. Figure 4 shows DTG curves for samples 2a-2d.

Peaks corresponding to weight loss of the above samples occur at $375,378,389$ and $400{ }^{\circ} \mathrm{C}$ (Fig. 4). A similar sequence is observed for all the systems studied, including the epoxy monomer. In the curve of the sample $\mathbf{2 a}$, an additional peak is observed at about $200{ }^{\circ} \mathrm{C}$ which most likely originates from the release of diethylenetriamine contained as a contamination in ethylenediamine. While comparing thermal stability of pure epoxy resin (3d) with that of pure crosslinked epoxy functional disiloxane (2d) and thermal stabilities of mixed systems $\mathbf{4 d}$ and $\mathbf{5 d}$ one can notice that the decomposition temperature, which is equal to $375{ }^{\circ} \mathrm{C}$ in the case of pure epoxy resin, increases with increasing contribution of siloxane fragment to the resin composition as shown in Fig. 5.

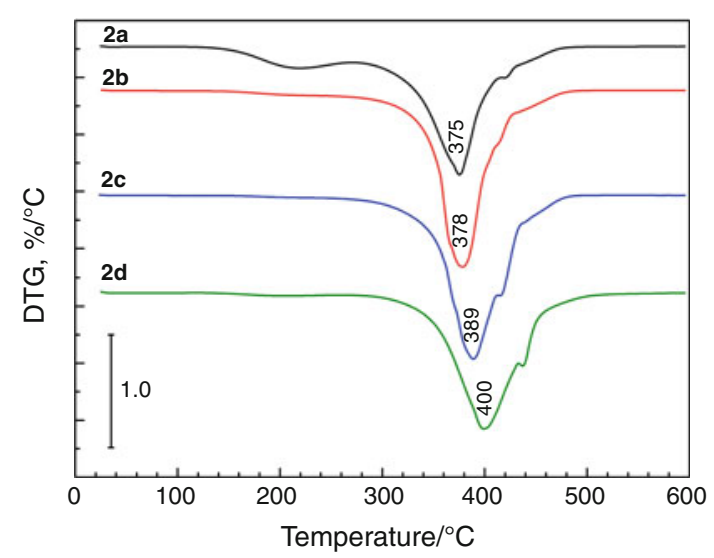

Fig. 4 DTG curves of products of crosslinking reactions of diepoxy disiloxane with 1,2-diaminoethane (2a), 1,3-diaminopropane (2b), 1,6-diaminohexane (2c) and 4,4,-diaminodiphenylmethane (2d)

The most interesting conclusions can be drawn from thermogravimetric analyses performed for materials obtained from crosslinked epoxy functional (poly)siloxanes. In Fig. 6, 


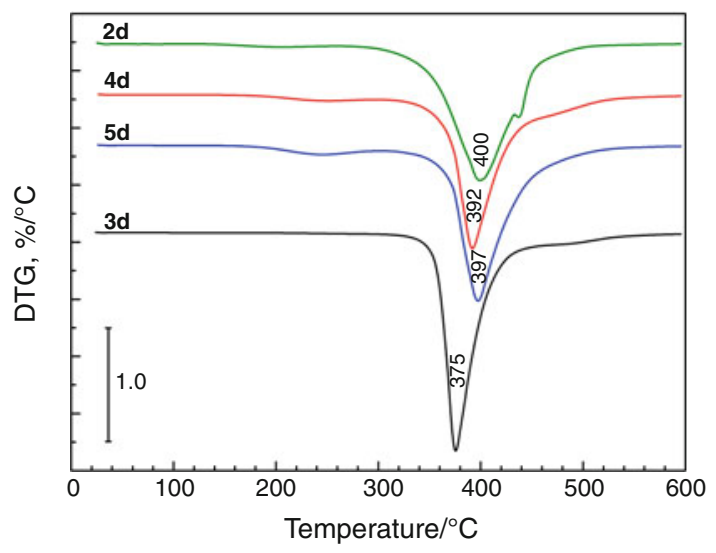

Fig. 5 DTG curves of products of crosslinking reactions of diepoxy disiloxane (2d), diglycidyl ether of bisphenol A (3d) and their mixtures prepared at the ratios of diepoxy disiloxane to diglycidyl ether of bisphenol A equal to 1:1 (4d) and 2:1 (5d) carried out in the presence of 4,4'-diaminodiphenylmethane

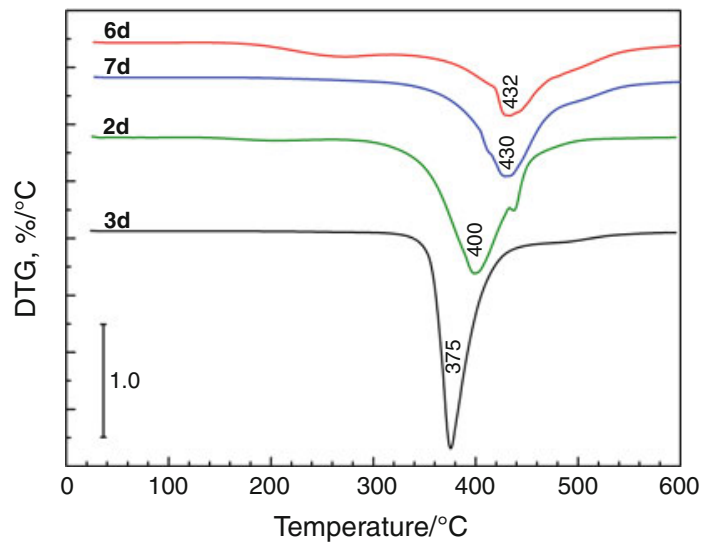

Fig. 6 DTG curves recorded during crosslinking reactions of (poly)siloxanes of different siloxane chain lengths and different contents of epoxy groups with 4,4'-diaminodiphenylmethane we have compared thermal stabilities (represented by DTG curves) of epoxy resin crosslinked with 4, $4^{\prime}$-diaminodiphenylmethane (3d), epoxy functional disiloxane (2d) and two epoxy functional polysiloxanes $\mathbf{6 d}$ and $\mathbf{7 d}$.

Peaks in DTG curves juxtaposed in Fig. 6 indicate that thermal decomposition temperatures of crosslinked samples based on epoxy functional (poly)siloxanes (430 and $432{ }^{\circ} \mathrm{C}$ for samples $\mathbf{7 d}$ and $\mathbf{6 d}$, respectively) are considerably higher than those of pure epoxy resin and pure epoxy functional disiloxane ( 375 and $400{ }^{\circ} \mathrm{C}$ for samples 3d and 2d, respectively).

Taking into consideration that most of samples investigated decompose near $400{ }^{\circ} \mathrm{C}$, we have juxtaposed weight losses of all crosslinked samples just at the above temperature. Juxtapositions of weight loss data recorded at $400{ }^{\circ} \mathrm{C}$ in nitrogen flow are given in Fig. 7.

It results from Fig. 7 that from among all samples those crosslinked with 4,4'-diaminodiphenylmethane (d samples) are the most thermally stable. Compared to samples based on pure epoxy resin (3a-3d), most of analogous samples based on pure epoxy functional siloxanes and polysiloxanes as well as mixed system samples (except for $\mathbf{2 a}$ and $2 \mathbf{b}$ ) were characterised by a higher thermal stability (as indicated by a smaller weight loss). The introduction of siloxane fragments into epoxy resin (samples $\mathbf{4}$ and 5) improved the thermal stability, however, a better effect (over twice as high thermal stability) was obtained in the case of hybrid materials based on epoxy functional polysiloxanes (samples 6 and 7). After completion of each thermogravimetric analysis, a black char residue was found on the thermobalance pan. The greatest amounts of the residue were formed in the case of polysiloxane-based hybrid materials, particularly in that of samples labelled 7 .
Fig. 7 Weight loss of crosslinked samples occurring at $400{ }^{\circ} \mathrm{C}$ in nitrogen

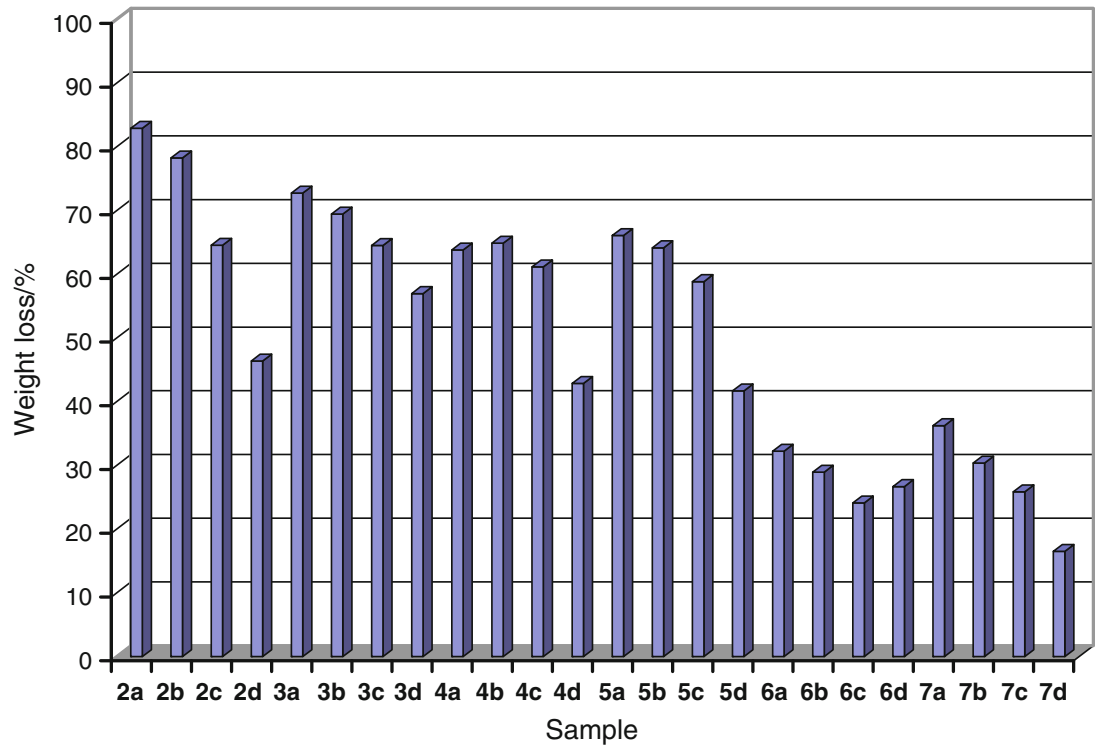




\section{Conclusions}

The obtained results have shown that epoxy functional siloxanes and polysiloxanes are very good precursors of hybrid materials. Studies of the model reaction of crosslinking between monoepoxy trisiloxane and diamines enabled to determine reaction conditions as well as to isolate and to fully characterise four reaction products by spectroscopic methods. Both the modification of epoxy resins with epoxy functional disiloxanes as well as the application of polysiloxanes with long polysiloxane chains and a specified content of epoxy groups make it possible to produce hybrid materials of very good thermal stability. One of the best crosslinking agents appeared to be $4,4^{\prime}$ diaminodiphenylmethane. In the presence of the latter compound, smooth, transparent and homogeneous coatings of high thermal stability were obtained in all cases studied. Moreover, DSC measurements have shown that crosslinking reactions carried out with the use of the above amino compound are characterised by the highest energetic effect from among the systems investigated. The highest thermal stability was found in the case of hybrid materials obtained from epoxy functional polysiloxanes.

Acknowledgements Financial support from the Ministry of Science and Higher Education (Poland), Grant No. N N 205273 635, is gratefully acknowledged.

Open Access This article is distributed under the terms of the Creative Commons Attribution Noncommercial License which permits any noncommercial use, distribution, and reproduction in any medium, provided the original author(s) and source are credited.

\section{References}

1. Gomez-Romero P, Sanchez C, editors. Functional hybrid materials. Weinheim: Wiley-VCH; 2004.

2. Kickelbick G, editor. Hybrid materials. Weinheim: Wiley-VCH; 2007.

3. Rurack K, Martinez-Manez R, editors. The supramolecular chemistry of organic-inorganic hybrid materials. Hoboken: Wiley; 2010.

4. Clarson SJ, Semlyen JH, editors. Siloxane polymers. New York: Prentice Hall; 1993.

5. Kircheldorf HR, editor. Silicon in polymer synthesis. Berlin: Springer; 1996.

6. Boileau S, Boury B, Ganachaud F, editors. Silicon based polymers. Berlin: Springer; 2008.

7. Jones RG, Ando W, Chojnowski J, editors. Silicon-containing polymers. Dordrecht: Kluwer Academic Publisher; 2000.

8. Brook MA. Silicon in organic, organometallic and polymer chemistry. New York: Wiley; 2000.

9. Crivello JV, Fen M. Novel platinum-containing initiators for ringopening polymerizations. J Polym Sci A Polym Chem. 1991;29: 1853-63.

10. Coqueret X, Hajaiej A, Lablache-Combier A, Loucheux C, Mercier R, Pouliquen L, Randrianarisoa-Ramanantsoa L. Synthesis and properties of photoreactive polysiloxanes containing pendant functional groups. Pure Appl Chem. 1990;62:1603-14.
11. Rutnakornpituk M. Modification of epoxy-novolac resins with polysiloxane containing nitrile functional groups: synthesis and characterization. Eur Polym J. 2005;41:1043-52.

12. Grunlan MA, Lee NS, Mansfeld F, Kus E, Finlay JA, Callow JA, Callow ME, Weber WP. Minimally adhesive polymer surfaces prepared from star oligosiloxanes and star oligofluorosiloxanes. J Polym Sci A Polym Chem. 2006;44:2551-66.

13. Crivello JV, Jang M. Synthesis of monomer and polymer-bound photosensitizers. J Macromol Sci A Pure Appl Chem. 2005;42:1-19.

14. Srividhya M, Madhavan K, Reddy BSR. Synthesis of novel soluble poly(imide-siloxane)s via hydrosilylation: characterization and structure property behaviour. Eur Polym J. 2006;42:2743-54.

15. Zhu X, Zhang M, Zhang Q, Feng S, Kong XZ. Synthesis and characterization of bis(methoxyl hydroxyl)-functionalized disiloxane and polysiloxane oligomers derivatives therefrom. Eur Polym J. 2005;41:1993-2001.

16. Dvorak DP, Soucek MD. Protective space coatings: a ceramer approach for nanoscale materials. Prog Org Coat. 2003;47:448-57.

17. Homrighausen CL, Teddy MK. Synthesis and characterization of a silarylene-siloxane-diacetylene polymer and its conversion to a thermosetting plastic. Polymer. 2002;43:2619-23.

18. Selvaraj R, Bhuvaneshwari B. Characterization and development of organic coatings for steel rebars in concrete. Port Electrochim Acta. 2009;27:657-70.

19. Shih WC, Chen-Chi MM. Tetrafunctional aliphatic epoxy I. Synthesis and characterization. J Appl Polym Sci. 1998;69:51-8.

20. Ahmad S, Ashraf SM, Hassan SN, Hasnat A. Synthesis, characterization and performance evaluation of hard, anticorrosive coating materials derived from diglycidyl ether of bisphenol A acrylates and methacrylates. J Appl Polym Sci. 2005;95:494-501.

21. Ahmad S, Ashraf SM, Sharmin E, Mohomad A, Alam M. Synthesis, formulation and characterization of siloxane-modified epoxy-based anticorrosive paints. J Appl Polym Sci. 2006;100:4981-91.

22. Kumar SA, Balakrishnan T, Alagar M, Denchev Z. Development and characterization of silicone/phosphorus modified epoxy materials and their application as anticorrosion and antifouling coatings. Prog Org Coat. 2006;55:207-2017.

23. Reusmann G. New epoxy-siloxane hybrid binder of high performance coatings. Macromol Symp. 2002;187:235-41.

24. Ahmad S, Gupta AP, Sharmin E, Alam M, Pandey SK. Synthesis, characterization and development of high performance siloxanemodified epoxy paints. Prog Org Coat. 2005;54:248-55.

25. Wu Q, Zhang Ch, Liang R, Wang B. Combustion and thermal properties of epoxy/phenyltrisilanol polyhedral oligomeric silsesquioxane nanocomposites. J Therm Anal Calorim. 2010;100:1009-15.

26. Özarslan Ö, Yildiz E, Inan TY, Kuyulu A, Güngör A. Novel amine terminated elastomeric oligomers and their effects on properties of epoxy resin as a toughener. J Appl Polym Sci. 2010;115:37-45.

27. Selvaraj R, Selvaraj M, Iyer SVK. Studies on the evaluation of the performance of organic coatings used for the prevention of corrosion of steel rebars in concrete structures. Prog Org Coat. 2009;64:454-9.

28. Yeh JM, Huang HY, Chen ChL, Su WF, Yu YH. Siloxane-modified epoxy resin-clay nanocomposite coatings with advanced anticorrosive properties prepared by a solution dispersion approach. Surf Coat Technol. 2006;200:2753-63.

29. Kumar SA, Sasikumar A. Studies on novel silicone/phosphorus/ sulphur containing nano-hybrid epoxy anticorrosive and antifouling coatings. Prog Org Coat. 2010;68:189-200.

30. González MG, Cabanelas JC, Pozuelo J, Baselga J. Preparation of cycloaliphatic epoxy hybrids with non-conventional amine-curing agents. J Therm Anal Calorim. 2011;103:717-23.

31. Ramirez C, Rico M, Barral L, Diez J, Garcia-Garabal S, Montero B. Organic/inorganic hybrid materials from an epoxy resin cured by an amine silsesquioxane. J Therm Anal Calorim. 2007;87:69-72.

32. Dworak DP, Soucek MD. Protective space coatings: a creamer approach for nanoscale materials. Prog Org Coat. 2003;47:448-57. 
33. Malucelli G, Amerio E. Epoxy-siloxane hybrid coatings by a dual-curing process. Adv Polym Technol. 2009;28:77-85.

34. $\mathrm{Hu} \mathrm{Ch}, \mathrm{Xu}$ G, Shen X, Shao Ch, Yan X. The epoxy-siloxane/Al composite coating with low infrared emissivity for high temperature applications. Appl Surf Sci. 2010;256:3459-63.

35. Qian M, Soutar AM, Tan XH, Zeng XT, Wijesinghe SL. Twopart epoxy-siloxane hybrid corrosion protection coatings for carbon steel. Thin Solid Films. 2009;517:5237-42.
36. Marciniec B, Maciejewski H, Szubert K, Kurdykowska M. Modification of (poly)siloxanes via hydrosilylation catalyzed by rhodium complex in ionic liquids. Monats Chem. 2006;137:605-11.

37. Maciejewski H, Szubert K, Marciniec B, Pernak J. Hydrosilylation of functionalized olefins catalysed by rhodium siloxide complexes in ionic liquids. Green Chem. 2009;11:1045-51. 